\title{
Gas vesicle formation and buoyancy regulation in Pelodictyon phaeoclathratiforme (Green sulfur bacteria)
}

\author{
Jörg Overmann, Susanme Lehmann, and Norbert Pfennig \\ Fakultät für Biologie, Universiläı Konstanz, Postfach 5560, W-7750 Konstanz, Federal Republic of Germany
}

Received March 27, 1991/Accepted August 5, 1991

\begin{abstract}
Gas vesicle formation and buoyancy regulation in Pelodictyon phaeoclathratiforme strain BU1 (Green sulfur bacteria) was investigated under various laboratory conditions. Cells formed gas vesicles exclusively at light intensities below $5 \mu \mathrm{mol} \cdot \mathrm{m}^{-2} \cdot \mathrm{s}^{-1}$ in the stationary phase. No effect of incubation temperature or nutrient limitation was observed. Gas space of gas vesicles occupied always less than $1.2 \%$ of the total cell volume. A maximum cell turgor pressure of $330 \mathrm{kPa}$ was determined which is comparable to values determined for cyanobacterial species. Since a pressure of at least $485 \mathrm{kPa}$ was required to collapse the weakest gas vesicles in Pelodictyon phaeoclathratiforme, short-term regulation of cell density by the turgor pressure mechanism can be excluded.

Instead, regulation of the cell density is accomplished by the cease of gas vacuole production and accumulation of carbohydrate at high light intensity. The carbohydrate content of cxponentially growing cells increased with light intensity, reaching a maximum of $35 \%$ of dry cell mass above $10 \mu \mathrm{mol} \cdot \mathrm{m}^{-2} \cdot \mathrm{s}^{-1}$. Density of the cells increased concomitantly. At maximum density, protein and carbohydrate together accounted for $62 \%$ of the total cell ballast. Cells harvested in the stationary phase bad a significantly lower carbohydrate content $(8-12 \%$ of the dry cell mass) and cell density $\left(1010-1014 \mathrm{~kg} \cdot \mathrm{m}^{-3}\right.$ with gas vesicles collapsed) which in this case was independent of light intensity. Due to the presence of gas vesicles in these cultures, the density of cells reached a minimum value of $998.5 \mathrm{~kg} \cdot \mathrm{m}^{3}$ at $0.5 \mu \mathrm{mol} \cdot \mathrm{m}^{-2} \cdot \mathrm{s}^{-1}$.

The cell volume during the stationary phase was three times higher than during exponential growth, leading to considerable changes in the buoyancy of Pelodictyon phaeoclathratiforme. Microscopic observations indicate that extracellular slime layers may contribute to these variations of cell volume.
\end{abstract}

Offprint requests to: J. Qvermanin
Key words: Green sulfur bacteria - Photosynthetic bacteria - Pelodictyon - Buoyancy - Gas vesicles - Turgor pressure - Cell ballast - Capsule - Slime capsule

Gas vesicles are hollow rigid structures which occur only in prokaryotic cells. The proteinaceous vesicle membrane is impermeable to liquid but permeable to gases. Because of their gas content, gas vesicles decrease the density of the cell and may provide neutral or even positive buoyancy if present in sufficient amounts.

About 80 bacterial and more than 60 cyanobacterial species, most of them planktonic, are known to contain gas vesicles (Walsby $1981 \mathrm{a}, \mathrm{b}$ ). Many of these species thrive in stratified freshwater lakes but are rarely encountered in isothermally mixed ones (Clark and Walsby 1978a). Others (Halobacterium sp.) are found in saline environments. Among marine cyanobacteria only three species of the genus Trichodesmizm contain gas vesicles (Walsby 1978). Recently, several gas-vacuolated heterotrophic bacterial strains were detected in the stratified sea ice environment of Antarctica (Staley et al. 1989; Irgens et al. 1989). This distribution pattern implies a selective advantage of gas-vacuolated bacteria only in non-turbulent aquatic habitats. Interestingly, most gasvacuolated bacteria are nonflagellated (exceptions are Lampracystis and Halobacterium).

So far, the investigation of buoyancy regulation in gasvacuolated cells and its significance for natural populations has focused mainly on cyanobacterial species. Among phototrophic sulfur bacteria gas vesicles are found in the genera Lamprobacter, Lamprocystis, Thiodictyon, Thiopedia, Amoebobacter (Chronatiaceae), in Ectothiorhodospira vacuolata (Ectothiorhodospiraceae), and in Pelodictyon, Ancalochloris, and Chloroherpeton (Green sulfur bacteria) (Cohen-Bazire et al. 1969; Pfennig and Trüper 1989). Little is known about density regulation in these microorganisms.

Recently, a new brown-colored species of the green sulfur bacteria, Pelodictyon phaeoclathratiforme, was de- 
scribed (Overmann and Pfennig 1989). In contrast to laboratory cultures, Pelodictyon cells in samples from Buchensee were highly gas-vacuolated. Therefore regulation of gas vesicle formation and buoyant density in pure cultures of Pelodictyon phaeoclathratiforme were investigated under various laboratory conditions.

\section{Material and methods}

\section{Cultivation}

Pelodictyon phaeoclathratiforme strain BU1 was grown in the basal medium deseribed by Overmann and Pfennig (1989). As substrates, thiosulfate ( $2 \mathrm{mM}$ ) and acclate $(4 \mathrm{mM}$ ) instead of sulfide were added aseptically to the autoclaved medium. To maintain reduced conditions, sterile $\mathrm{Na}_{2} \mathrm{~S}$ and $\mathrm{Na}_{2} \mathrm{~S}_{2} \mathrm{O}_{4}$ solutions were added to a final concentration of $200 \mu \mathrm{M}$, each. With the exception of the very first hours of incubation, cells in this modified medium did not form extracellulat sulfur globules (Overmann and Pfennig 1989) which would interfere with growth and buoyancy measurements. Furthermore, the $\mathrm{pH}$ in the cultures remained stable and higher biomass yields were reached without repeated addition of neutralized sulfide solution.

Cultures were grown in $250 \mathrm{~m} 1$ screw cap Meplats bottles to minimize light focusing inside the vessel. The effects of different light intensities were investigated in a light cabinet using daylight fluorescent tubes (Osram daylight 5000 de luxe). Eight intensity was measured with a LiCor (Lincoln, Nebraska, USA) 185B quantum meter equipped with a $\mathrm{Li} 200 \mathrm{SB}$ quantum sensor. The mean light intensity $r$ in the cultures was calculated from intensities in front $\left(I_{1}\right)$ and behind $\left(I_{2}\right)$ the bottles according to:

$\mathrm{I}=\left(\mathrm{I}_{1}-\mathrm{I}_{2}\right) / \ln \left(\mathrm{I}_{1} / \mathrm{I}_{2}\right)$

(Van Liere and Walsby 1982). During the experiments, the mean light intensity was adjusted in 24 -h intervals. The influence of different temperatures was assessed in thermo-regulated water baths at saturating light intensitics $\left(150 \mu \mathrm{mol} \cdot \mathrm{m}^{-2} \cdot \mathrm{s}^{-1}\right.$ tungsten light). Growth was followed by measuring the optical density at $650 \mathrm{~nm}$ (Bausch \& Lomb, Rochester, NY, USA, Spectronic 70 photometer). To examine the effect of nutrient limitation on gas vesicle formation, culture media with lowered concentration of either $\mathrm{NH}_{4}^{+}(1 \mathrm{mM}=$ $16 \%$ of the usual concentration), $\mathrm{PO}_{4}^{3-}(400 \mu \mathrm{M}=16 \%)$, or $\mathrm{Ca}^{2+}$ $\left(200 \mu \mathrm{M}=10^{\circ} \%\right)$ were applied. The ions were replaced by $\mathrm{K}^{+}, \mathrm{Cl}^{-}$ or $\mathrm{Mg}^{2+}$, respectively, to maintain the salt concentration of the media. Growth yiclds in these media were significantly lower than in standard medium proving nutrient limitation of growth.

\section{Gas vesicle measurements}

The presence of gas vacuoles in Pelodictyon cells was examined microscopically. The relative gas vesicle content (RGV) was estimated from the ratio of pressure scnsitive turbidity $\left(\Delta \mathrm{T}_{\mathrm{a}}\right)$ to the remaining turbidity $\left(T_{c}\right.$ ) (Walsby 1971). A pressure of $1200 \mathrm{kPa}$ ensured quantitative collapse of the gas vesicles.

Critical pressure collapse curves of gas vesicles were determined using the pressure nephelometer described by Walsby (1973). From the curves mean critical pressures $\left(\bar{p}_{a}\right.$, pressure causing the collapse of $50 \%$ of the gas vesicles) were calculated. Cell turgor pressure $P$ was determined by the difference $P=\bar{p}_{c}-\bar{p}_{a}$, with $\bar{p}_{c}$ measured for cells suspended in culture medium containing $0.5 \mathrm{M}$ sucrose and $\bar{p}_{n}$ for those suspended in culture medium alone (Walsby 1971). To determine the sucrose concentration sufficient for complete removal of the coll turgor pressure, a series of collapse-pressure curves at

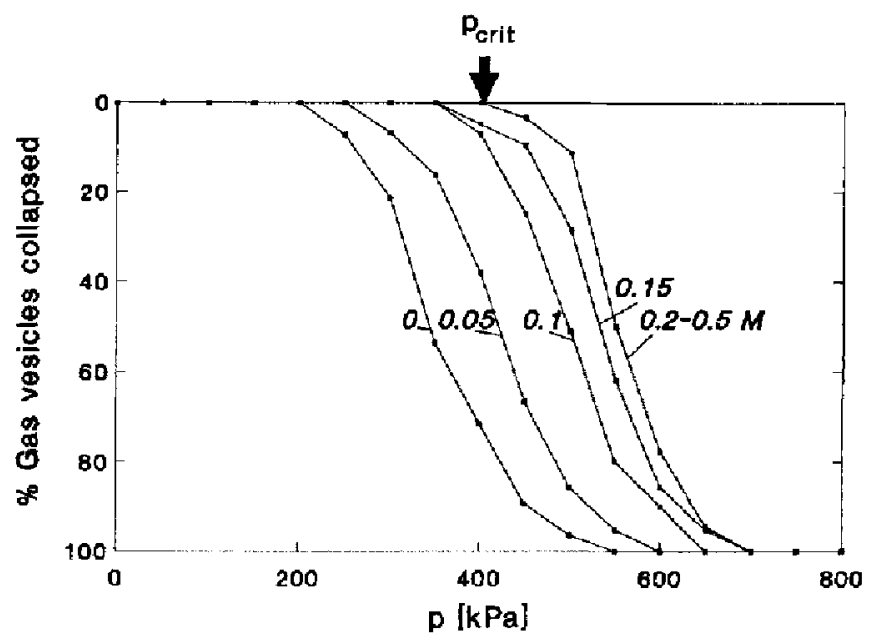

Fig. 1. Series of pressure collapse curves as obtained by nephelometry of a gas-vacuolated suspension of Pelodictyon phaeoclathratiforme BU1. At increasing external pressure $\mathrm{p}$ an increasing percentage of gas vesicles are collapsed. Depencing on the external sucrose concentration (indicated by the number at each curve), the cell turgor is released and higher pressures are required to collapse the vesictes. The total pressure $p_{c t 1}$ tolerated by the weakest gas vesicles is indicated

concentrations between 0 and $0.5 \mathrm{M}$ sucrose was used (Fig. 1). Highly turgid cells ( $P=200 \mathrm{kPa}$ ) were used in the experiment. Between 0.2 and $0.5 \mathrm{M}$ sucrosc no further shift of the collapse curves was obscrved indicating complete release of the cell turgor at these concentrations (compare $P$ in Fig. 2). To test the possible penetration of sucrose into the cells, a sample containing $0.35 \mathrm{M}$ sucrose was incubated 2 and $13 \mathrm{~h}$ prior to the measurement. Only a very small decrease of $\bar{p}_{u}(-1.7 \%)$ was determined after $2 h$ and even an increase after $13 \mathrm{~h}$ of incubation. Therefore penetration of sucrose into the cells can be excluded. The curve of the remaining turgor pressure $P^{\prime}$ at ench sucrose concentration shoud follow the expression $\mathrm{P}^{\prime}=\pi_{\mathrm{i}}-\pi_{\mathrm{B}}=\mathrm{P}-\pi_{\mathrm{e}}$, where $\pi_{\mathrm{l}}$ is the internal and $\pi_{\mathrm{e}}$ the external osmotic pressure. An equivalent osmotic pressure of $2750 \mathrm{kPa} /\left(\mathrm{M}\right.$ sucrose) was assumed to calculate $\pi_{e}$. The lurgor pressure abserved deviates from the idcal line given by the expression above (compare $\mathrm{P}^{r}$ and dashed line in Fig. 2). This indicates that the internal osmotic pressure decreases and the cells shrink at higher sucrose concentrations. The relative cell water volume $V_{w}$ at different sucrose concentrations can be calculated according to $\mathrm{V}_{\mathrm{w}}=\mathrm{P} /$ $\left(\mathbf{P}^{r}+\pi_{\mathrm{e}}\right.$ ) (Walsby 1980), $\mathbf{P}$ being the turgot of cells suspended in medium. Relative cell water volume reached $20 \%$ at $0.5 \mathrm{M}$ sucrose compared to cells in medium alone (Fig. 2). Figure 2 is very similar to corresponding results for cyanobacteria (Walsby 1980) and proves that the method of turgor determination can be applied also to $P$. phaevelatiratiforme.

The gas space of gas vesicles was measured with a capillary compression tube (Walshy 1982). Prior to the measurement the cell suspension was evacuated for $20 \mathrm{~min}$ to remove dissolved gases. This prevented the formation of gas bubbles during the experiment. The reservoir and capillary were filled and placed in a thermostatted pressure tube. When equilibrium was reached the sample was pressurized momentarily to $1200 \mathrm{kPa}$ and the volume of gas vesicle gas space was calculated from the change in position of the meniscus in the capillary. flasks.

During all experiments it was avoided to rock or jolt the culture

\section{Analytical procedures}

Protein was measured after Hartree (1972). For calibration standard solutions of bovine serum albumin were used. Carbohydrate concen- 


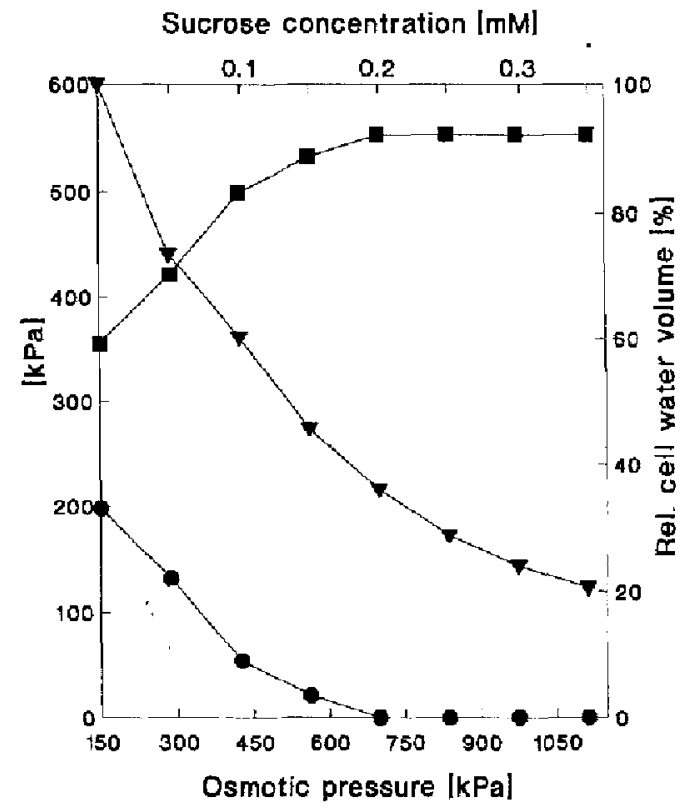

Fig. 2. Mean critical pressure (rectangles), urgor pressure (circtes), and relative cell water volume (triangles) at increasing osmotic pressure. Dashed line indicates decrease of turgor pressurc if the internal osmotic pressure would remain constant

tration in the cells was determined with the anthrone method (Herbert et a1. 1971) and calibrated with standard solutions of D-glucose. The weight of carbohydrate was estirnated as $162 / 180$ of the glucose equivalent to allow for water of condensation.

Dry cell mass was measured after filtering $3.5-15 \mathrm{ml}$ of the culture through predried $\left(105^{\circ} \mathrm{C}, 24 \mathrm{~h}\right)$ and weighed membranc filters (cellulose-acetate, $2.5 \mathrm{~cm}$ in diameter, pore size $0.2 \mu \mathrm{m}$, Schleicher \& Schüll, Dassel, $\mathrm{HRG}$ ), and redrying at $105^{\circ} \mathrm{C}$ for $24 \mathrm{~h}$.

The density of unpressurized and pressurized $(1200 \mathrm{kPa})$ Pelodictyon cells was determined by isopycnic banding on continuous gradients of silica-sol (Percoll, Sigma Chemie, Deisenhofen, FRG; Oliver al al. 1981). Gradients were formed by centrifugation of 10-ml samples made of $5 \mathrm{ml}$ Percoll, $1 \mathrm{ml}$ ten-fold concentrated culture medium (omitting thiosulfate, acetate, and carbonate buffer) and $4 \mathrm{ml}$ distilled water (Sorvall, Du Pont, Bad Homburg. FRG, Model RC-5B, in a fixed angle rotor SS 34 at $39100 \times g$ for $1 \mathrm{~h}$ at $10^{\circ} \mathrm{C}$ ). The density gradient formed ranged from 995 to $1042 \mathrm{~kg} \cdot \mathrm{m}^{-3}$. It was overlaid with $1 \mathrm{ml}$ of the culture and recentrifuged in a swing-out rotor (Sorvall HB-4) at $363 \times \mathrm{g}$ for $40 \mathrm{~min}$. The density of the bacterial layer was determined by measuring the refractive index (Bausch \& Lomb refractometer). For calibration, a dilution series of Percoll was prepared.

To determine the cell volume, two methods were iried. First, a concentrated suspension of Pelodictyor cells was mixed with blue stained Percoll (Simplicol azurc textile colour) and centrifuged. The cell volume was estimated from optical density and volume of the superuatant and the pellet volume according to Oliver and Walsby (1984). A higher centrifugation speed than in the original method was necessary for sedimentation of the cells. The method always yielded negative cell volume values. This indicates that, parallel to the Pelodictyon cells also the stained Percoll itself concentrated during centrifugation in the pellet.

Therefore, cell volumes were determined after a second method. Collapsing the gas vesicles causes a sudden decrease of the cell tuigor which is compensated for by penetration of water mto the cell. The replacement of gas (density: $1.2 \mathrm{~kg} \mathrm{~m}^{-3}$ at $100 \mathrm{kPa}$ and a mixture in the culture medium of $\mathrm{N}_{2}: \mathrm{CO}_{2}=90: 10$ ) by water (density at $20^{\circ} \mathrm{C}: 998 \mathrm{~kg} \cdot \mathrm{m}^{-3}$ ) and hence the density difference $(\delta \mathrm{d})$ between unpressurized and pressurized cells thus provides an estimate of the

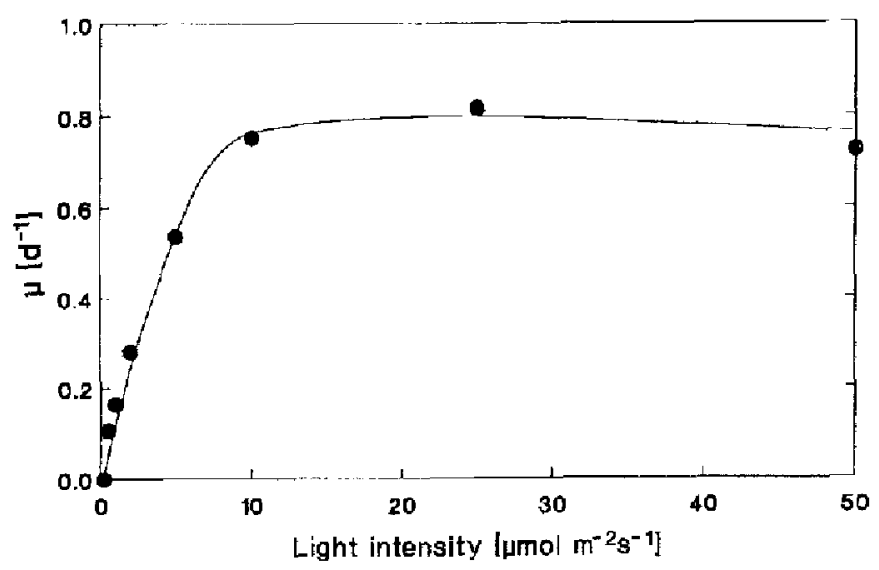

Fig. 3. Dependence of growth rate on light intensity for Pelodictyon phaeoclathratiforme strain BU1

part of the cell wolume $V_{\text {ret }}$ occupied by gas vesicle gas inside the cells:

$\mathrm{V}_{\mathrm{rel}}\left(\mathrm{m}^{3} \mathrm{gas} / \mathrm{m}^{3}\right.$ cell volume $)=\delta \mathrm{d}\left(\mathrm{kg} \cdot \mathrm{m}^{-3}\right),[998.0-1.2]\left(\mathrm{kg} \cdot \mathrm{m}^{-3}\right)$

The absolute valuc of gas vesicle gas space per $\mathrm{m}^{3}$ medium $\left(\mathrm{V}_{\mathrm{g} \mathbf{a}}\right)$ was determined with the capillary compression tube (see above). Thus, the cell volume $V_{\text {cell }}$ per $\mathrm{m}^{3}$ medium can be calculated according to:

$V_{\text {cell }}\left(\mathrm{rn}^{3} / \mathrm{m}^{3} \operatorname{medium}\right)=\mathrm{V}_{\mathrm{gas}} / \mathrm{V}_{\mathrm{rel}}$.

However, the inflow of water after collapse of the gas vesicles decreases the internal osmotic pressure. As a consequence, the volume of water entering is less than the gas vesicle gas space it replaces. The deviation was determincd to be $27 \%$ in Anabaena lemmermanni (Walsby et al. 1991). This is much lower than the changes in cell volume calculatcd for Pelodictyon phaeoclathratiforme (see 'Results' section). Thus the deviation does not affect the conclusions drawn below.

The ballast mass of cell protein and carbohydrate was calculated by subtracting from the mass of the substance the mass of water it displaces. Density of cell protein and carbohydrate was assumed to be 1300 and $1600 \mathrm{~kg} \cdot \mathrm{m}^{-3}$ respectively (Oliver and Walsby 1984).

\section{Results}

Induction of gas vesicle formation

The growth rates of Pelodictyon phaeoclathratiforme $\mathrm{BU} 1$ were light-limited below $10 \mu \mathrm{mol} \cdot \mathrm{m}^{-2} \cdot \mathrm{s}^{-1}$ and ceased at $0.25 \mu \mathrm{mol} \cdot \mathrm{m}^{-2} \cdot \mathrm{s}^{-1}$ (Fig. 3). The cells formed gas vesicles exclusively at low light intensities $(<5 \mu \mathrm{mol}$ $\cdot \mathrm{m}^{-2} \cdot \mathrm{s}^{-1}$ ). A higher degree of gas vacuolation was observed when cultures were preincubated at $10 \mu \mathrm{mol}$ $\cdot \mathrm{m}^{-2} \cdot \mathrm{s}^{-1}$ and then snifted to $0.25 \mu \mathrm{mol} \cdot \mathrm{m}^{-2} \cdot \mathrm{s}^{-1}$. In contrast, gas vacuoles did not appear after a shift to dark conditions. No effect of incubation temperature or nutrient limitation was found for cells growing at lightsaturation $\left(150 \mu \mathrm{mol} \cdot \mathrm{m}^{-2} \cdot \mathrm{s}^{-1}\right)$ (Table 1 ).

\section{Regulation of cell density}

To differentiate the role of gas vesicles from the role of other cell constituents in buoyancy regulation, the cell 
Table 1. Formation of gas vesicles in Pelodictyon phacoclathratiforne $\mathrm{BU} 1$ at various experimental conditions. Experiments lasted for 2 weeks at different light intensities and for 4 weeks in temperature and nutrient limitation experiments. In transfer experiments, cultures were shifted after reaching an optical density at $650 \mathrm{~nm}$ of 0.3
Conditions

Formation

of gas

vacuoles

$150,75,30,10 \mu \mathrm{mol} \cdot \mathrm{m}^{-2} \cdot \mathrm{s}^{-1}, 20^{\circ} \mathrm{C}$

$5,1,0.5 \mu \mathrm{mol} \cdot \mathrm{m}^{-2} \cdot \mathrm{s}^{-1}, 20^{\circ} \mathrm{C}$

$150 \mu \mathrm{mol} \cdot \mathrm{m}^{-2} \cdot \mathrm{s}^{-1}, 7^{\circ} \mathrm{C}$

$\mathrm{NH}_{4}^{+}, \mathrm{PO}^{3}{ }_{4}, \mathrm{Ca}^{2+}$ depleted medium, $150 \mu$ mol $\cdot \mathrm{m}^{-2} \cdot \mathrm{s}^{-1}, 20^{\circ} \mathrm{C}$

$\mathrm{NH}_{4}^{+}, \mathrm{PO}^{3}{ }_{4}^{-}, \mathrm{Ca}^{2+}$ depleted medium, $150 \mu \mathrm{mol} \cdot \mathrm{m}^{-2} \cdot \mathrm{s}^{-1}, 7^{\circ} \mathrm{C}$

Preincubation $150 \mu \mathrm{mol} \cdot \mathrm{m}^{-2} \cdot \mathrm{s}^{-1}, 20^{\circ} \mathrm{C}$; transfer to dark

Preincubation $150 \mu \mathrm{mol} \cdot \mathrm{m}^{-2} \cdot \mathrm{s}^{-1}, 7^{\circ} \mathrm{C}$; transfer to datk

Preincubation $10 \mu \mathrm{mol} \cdot \mathrm{m}^{2} \cdot \mathrm{s}^{1}, 20^{\circ} \mathrm{C}$; transfer to $0.25 \mu \mathrm{mol} \cdot \mathrm{m}^{-2} \cdot \mathrm{s}^{-1}+$

Preincubation $1 \mu \mathrm{mol} \cdot \mathrm{m}^{-2} \cdot \mathrm{s}^{-1}, 20^{\circ} \mathrm{C}$; transfer to $0.25 \mu \mathrm{mol} \cdot \mathrm{m}^{-2} \cdot \mathrm{s}^{-1}$ -

Preincubation $10 \mu \mathrm{mol} \cdot \mathrm{m}^{-2} \cdot \mathrm{s}^{-1}, 20^{\circ} \mathrm{C}$; transfer to $7^{\circ} \mathrm{C}, 10 \mu \mathrm{mol} \cdot \mathrm{m}^{-2} \cdot \mathrm{s}^{-1}$
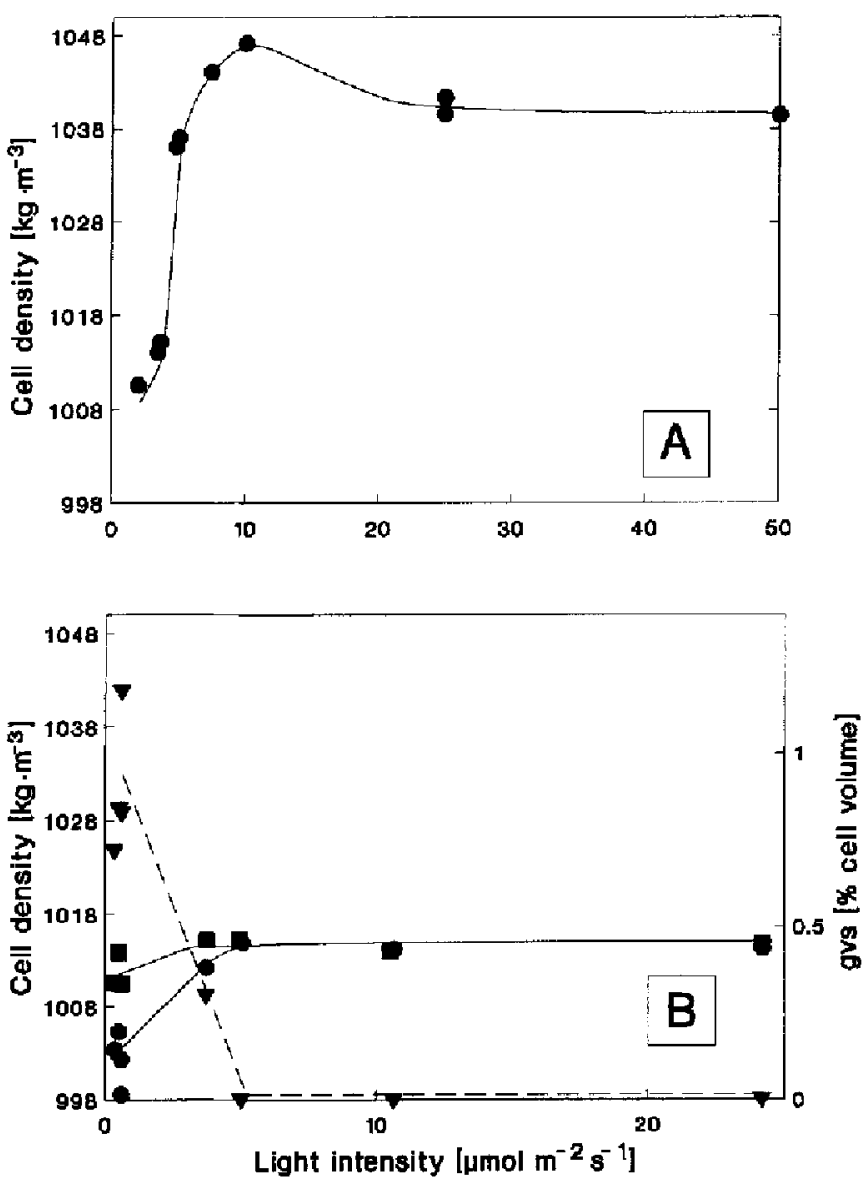

Fig. 4. A Cell density of exponentially growing Pelodictyon phaeoclathratiforme ceils at different light intensities. No differences between pressurized and unpressurized cells were observed. B Cell density of pressurized (rectangles) and unpressurized cells (circles) in the stationary phase at different light intensities. Triangles indicate the percentage of cell volume occupied by gas vesicle gas space (gvs)

density in cultures grown at different illumination $(0.5-$ $50 \mu \mathrm{mol} \cdot \mathrm{m}^{-2} \cdot \mathrm{s}^{-1}$ ) was determined for pressurized and unpressurized samples (Fig. 4). Cells were harvested in the exponential growth phase (at $\mathrm{OD}_{650}=0.6-$ $0.7 \mathrm{~cm}^{-1}$ in the growth medium applied), and in the late stationary phase $\left(\mathrm{OD}_{650}=0.6-0.7 \mathrm{~cm}^{-1} ;\right.$ compare $\mathrm{OD}_{650}$ curve in Fig. 6). Density of cells growing exponentially under light limitation increased markedly with light

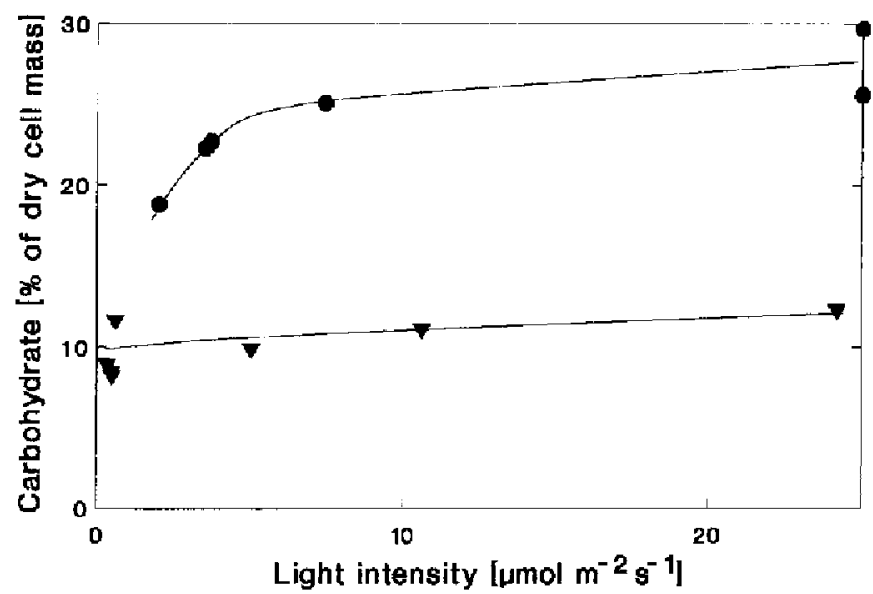

Fig. 5. Carbohydrate content (in percent of dry celt mass) of Pelodictyon phaeoclathratiforme cells in the exponential (circles) and stationary phase (rriangles)

intensity and reached a maximum value at $10 \mu \mathrm{mol}$ $\cdot \mathrm{m}^{-2} \cdot \mathrm{s}^{-1}$. A slight drop was observed at higher intensitics. Pressurizing the cells did not alter their density (Fig. 4A). In the late stationary phase, however, the density of pressurized cells remained low and almost constant at different light intensities. The gas vesicle content of non-growing cells was inversely related to the light intensity (Fig. 4B). Similar to the induction experiments, formation of gas vesicles was observed only below $5 \mu \mathrm{mol} \cdot \mathrm{m}^{-2} \cdot \mathrm{s}^{-1}$. In none of the experiments positively buoyant cells (rising to the top of the culture flask and having densities $<998 \mathrm{~kg} \cdot \mathrm{m}^{-3}$, compare Fig. 4) were observed.

The respective carbohydrate content of the cultures compared well with the density (Fig. 5), while variations in the protein content were considerably smaller (23.5$49 \%$ of dry cell mass). Carbohydrates have a much higher density than protein and varied by a factor of more than 3 compared to a factor of 2 in case of protein. Our results therefore indicate that the carbohydrate content of Pelodictyon cells is of major significance in regulating the cell density.

To investigate the time course of changes in cell density and ballast components (carbohydrate and protein), stationary Pelodictyon cells grown at $0.5 \mu \mathrm{mol} \cdot \mathrm{m}^{-2} \cdot \mathrm{s}^{-1}$ 


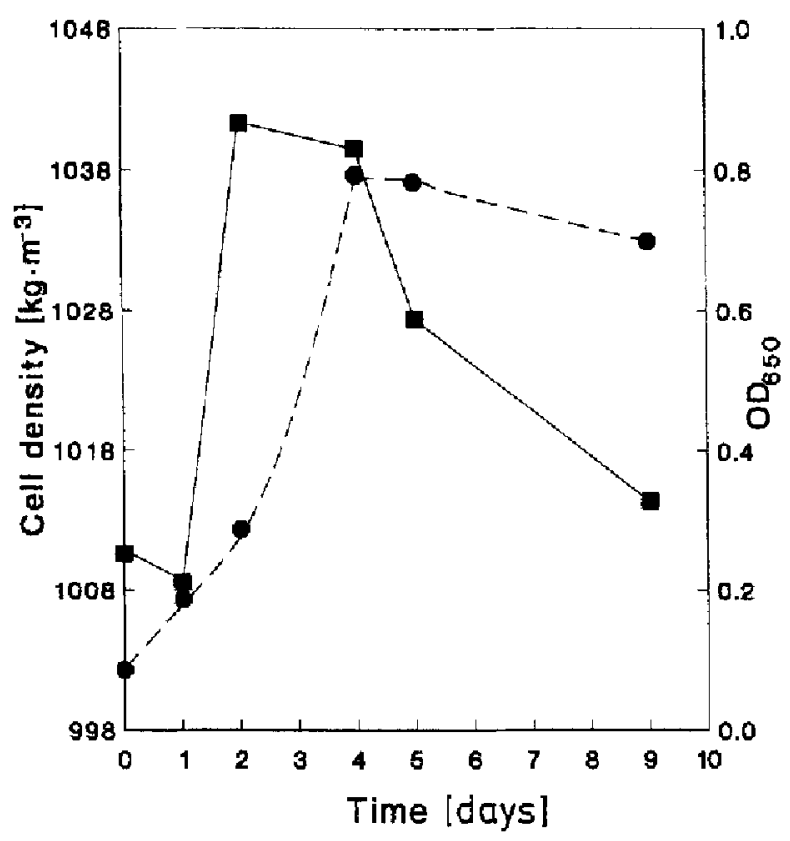

Fig. 6. Time course of optical density at $650 \mathrm{~nm}$ (circles) and buoyant density of pressurized Petodictyon phaeoclathratiforme cells (rectangles) after shift of low light adapted cells to saturating light intensities of $25 \mu \mathrm{mol} \cdot \mathrm{m}^{-2} \cdot \mathrm{s}^{-1}$

were inoculated into fresh medium and incubated at saturating light intensities $\left(25 \mu \mathrm{mol} \cdot \mathrm{m}^{-2} \cdot \mathrm{s}^{-1}\right)($ Fig. 6). During the subsequent exponential growth phase, the density of pressurized cells increased sharply and remained constant until the stationary phase was reached. As soon as growth terminated the density decreased, reaching almost the initial values. Although there was a pronounced increase of cell carbohydrate content during the first day of incubation (Fig. $7 \mathrm{~B}$ ), there was no increase of density. On the other hand, the marked increase of density during the sccond day of incubation is in contrast to almost constant carbohydrate content.

Comparing the cell volume at the beginning of the experiment with that at muximum density (Table 2, arrows in Fig. 7) revealed a decrease by a factor of more than three. During the first two days of incubation the cell volume increased temporarily from 20.1 to $40.4 \mu \mathrm{l}$ - (mg dry cell mass) ${ }^{-1}$ thus compensating the concomitant increase in carbohydrate content. As the cell volume calculation for Pelodictyon was confined to gas-vacuolated cells, no values could be obtained for the stationary growth phase. Assuming the cell volume to remain constant after the second day of incubation, the ballast mass of protein and carbohydrate was calculated. The sum of both ballast components decreased only slightly, as the decrease of carbohydrate was compensated for in part by decreasing protein content (Table 2). However, the actual cell density observed was significantly lower than indicated by the ballast calculation. This strongly indicated an increase of cell volume during the stationary growth phase. To directly investigate the causes of cell volume changes in the microscope, $0.5 \mathrm{ml}$ of the bacterial culture was mixed with $0.1 \mathrm{ml}$ Indian ink and photographs were taken applying agar coated slides (Pfennig and Wagener
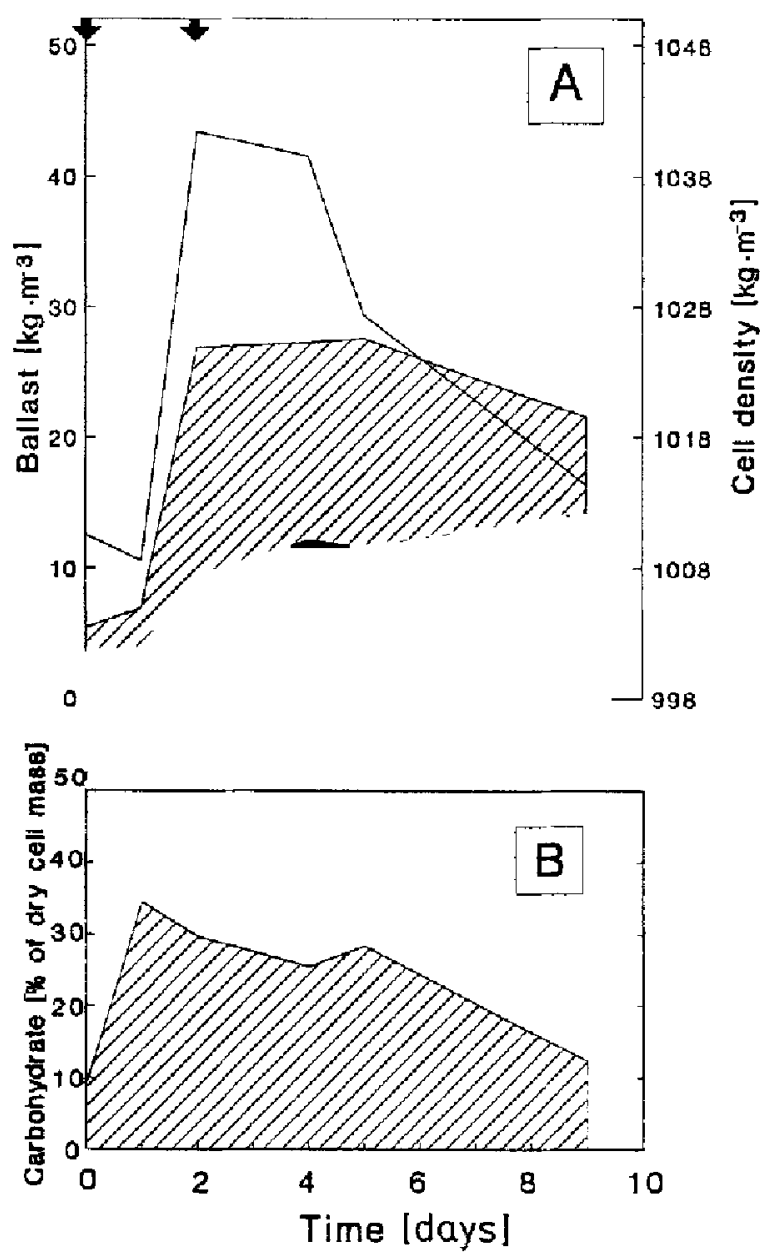

Fig- 7. A Time course of protein ( $(i l l e d)$ and carbohydrate ballast (hatched) during the experiment shown in Fig. 7. Line indicates total density of cells Arrows correspond to the cell volume values listed in Table 2. B Carbohydrate content (percent of dry cell mass)

1986). Care was taken to avoid compression of the cells due to drying of the samples. Fig. 8 indicates that a major portion of cell volume has to be attributed to slime layers surrounding the Pelodictyon cells. The widths of the slime layers was 5.7 timcs the cell diameter in cells grown at $0.5 \mu \mathrm{mol} \cdot \mathrm{m}^{-2} \cdot \mathrm{s}^{-1}$ (Fig. 8A) but only 3.4 times during exponential growth at $25 \mu \mathrm{mol} \cdot \mathrm{m}^{-2} \cdot \mathrm{s}^{-1}$ (Table 3). Dimensions of cells, grown at $25 \mathrm{mmol} \cdot \mathrm{m}^{-2} \cdot \mathrm{s}^{-1}$ in the stationary phase were similar to those of cells at $0.5 \mu \mathrm{mol}$ $\cdot \mathrm{m}^{-2} \cdot \mathrm{s}^{-1}$ (Table 3).

Although variation of the cell volume seems to be the dominating process during density regulation of Pelodictyon phaeoclathratiforme, an increasing portion of total batlast mass ( = cell density minus $998 \mathrm{~kg} \cdot \mathrm{m}^{-3}$, the density of water) is explained by protein plus carbohydrate ballast $(43.2 \%$ at day $0,62.0 \%$ of total ballast at day 2$)$. This indicates that both cell constituents, and especially carbohydrates, have a certain impact on density regulation. If changes of cell density would be due only to variation of cell volume, the portion of protein plus carbohydrate ballast mass should remain constant. 
Table 2. Protein, carbohydrate content and cell volume of Pelodictyon phaeoclathratiforme BU1 during the experiment shown in Figs. 6,7 and 9

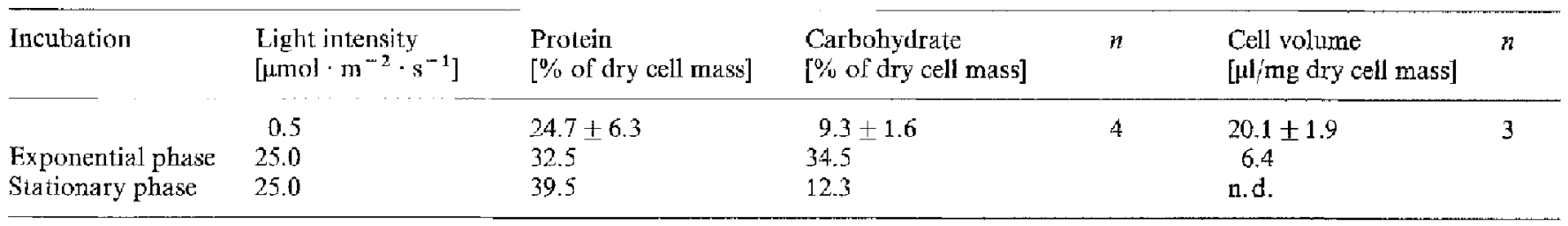

n. d. = not determined
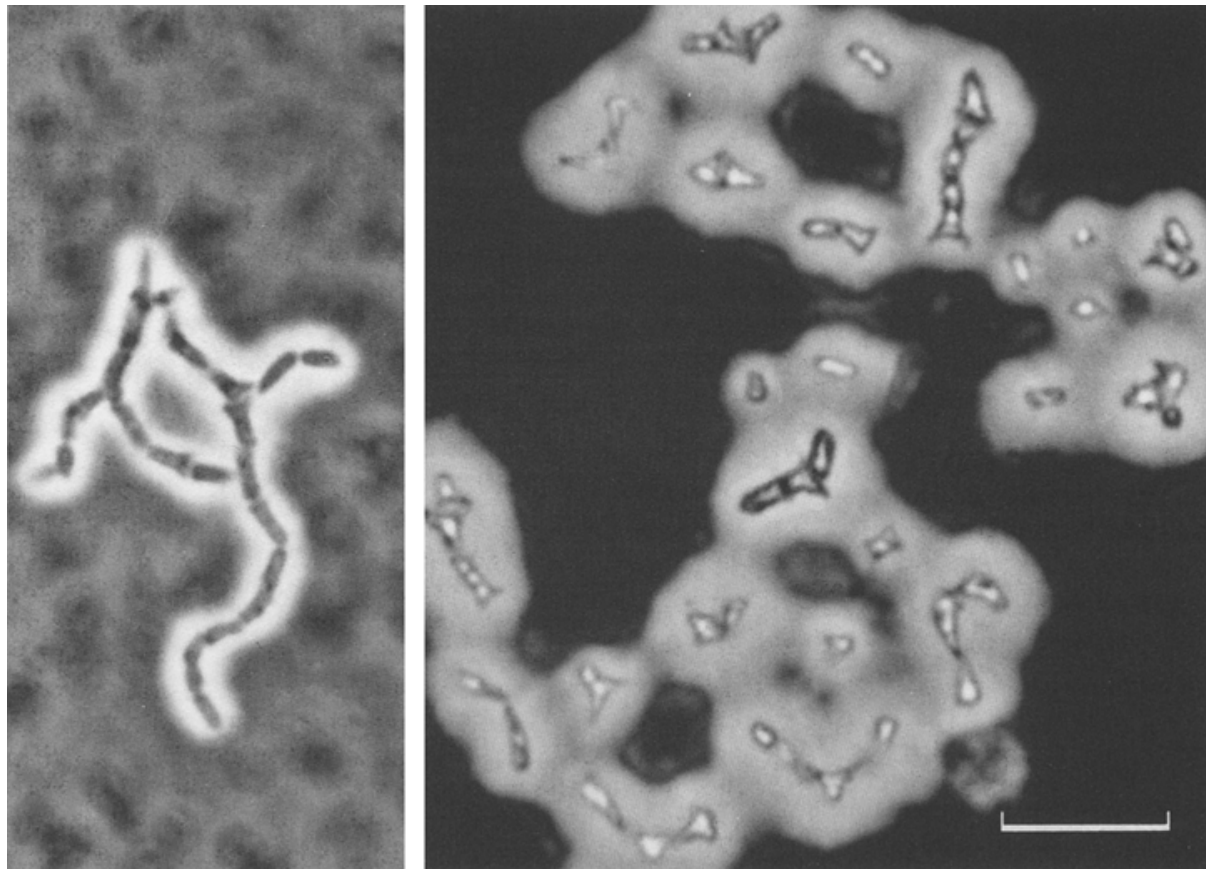

Fig. 8. Phase contrast photomicrograph of Pelodictyon phaeoctathratiforme cells from the stationary phase (incubated at $0.5 \mu \mathrm{mol} \cdot \mathrm{m}^{-3} \cdot \mathrm{s}^{-1} ;$ right and from the exponential growth phase $\left\{25 \mu \mathrm{mol} \cdot \mathrm{m}^{-2}\right.$ $\left.\cdot{ }^{1}{ }^{1} ; l e f t\right)$. Cells suspended in Indian ink Halo around cells is caused by thick extracellular slime layers. $B a r=10 \mu \mathrm{m}$

Table 3. Dimensions of Pelodictyon phateoclathratiforme cells with and without extracellular slime layers as estimated from photomicrographs of Indian ink preparations

\begin{tabular}{lll}
$\begin{array}{l}\text { Light intensity } \\
{\left[\mu \mathrm{mol} \cdot \mathrm{m}^{-2} \cdot \mathrm{s}^{-1}\right]}\end{array}$ & \multicolumn{1}{c}{ Ccll dimensions } \\
\cline { 2 - 3 } & & \multicolumn{1}{c}{$\begin{array}{l}\text { Plus extracellular } \\
\text { layers }\end{array}$} \\
\hline 0.5 & $1.86 \times 0.75 \mu \mathrm{m}$ & $5.45 \times 4.29 \mu \mathrm{m}$ \\
& $0.55 \mu \mathrm{m}^{3} \mathrm{a}$ & $52.52 \mu \mathrm{m}^{3}$ \\
25.0 & $2.16 \times 0.71 \mu \mathrm{mm}$ & $3.39 \times 2.39 \mu \mathrm{m}$ \\
Exponential & $0.57 \mu \mathrm{m}^{3}$ & $10.14 \mu \mathrm{m}^{3}$ \\
$\quad$ growth phase & $2.45 \times 0.83 \mu \mathrm{m}$ & $5.10 \times 4.22 \mu \mathrm{m}$ \\
25.0 & $0.84 \mu \mathrm{m}^{3}$ & $47.11 \mu \mathrm{m}^{3}$ \\
\hline Stationary phase &
\end{tabular}

a Volumes calculated by applying the formula of a rotational ellipsoid

Role of cell turgor in the loss of gas vesicles

Short-term regulation of gas vesicle content by increasc of cell turgor pressure is a common regulation mechanism among cyanobacteria (Oliver and Walsby 1984). In such species, turgor pressure in cells grown at high light inten- sity exceeds the pressure necessary to collapse the weakest. gas vesicles (critical pressure perit, Fig. 1). A valuc of $\mathrm{p}_{\text {crit }}=(485 \pm 24) \mathrm{kPa}(n=10)$ was determined for Pelodictyon phaeoclathratiforme (dashed line in Fig. 9). The maximum cell turgor pressure reached in the cells during exponential growth was far less $(332 \mathrm{kPa}$ ) than $\mathrm{p}_{\text {erit, }}$, thus excluding active collapse of gas vesicles (Fig. 9).

\section{Discussion}

Three different mechanisms are involved in buoyancy regulation of Pelodictyon phaeoclathratiforme: variation of the gas vesicle content, of the carbohydrate content, and of total volume of the cells.

Variations in gas vacuolation are accomplished by formation and slow decay of gas vesicles (Fig. 9). Formation of gas vacuoles in Pelodictyon phaeoclathratiforme BU1 was only observed at very low light intensities below $5 \mu \mathrm{mol} \cdot \mathrm{m}^{-2} \cdot \mathrm{s}^{-1}$. Obviously this is the reason for the rare observation of gas vacuoles in laboratory cultures which are routinely incubated at higher light intensities. Low incubation temperature or nutrient deficiency did not effect the gas vacuolation in this strain. Our results partly agree with those of Pfennig and Cohen-Bazire 


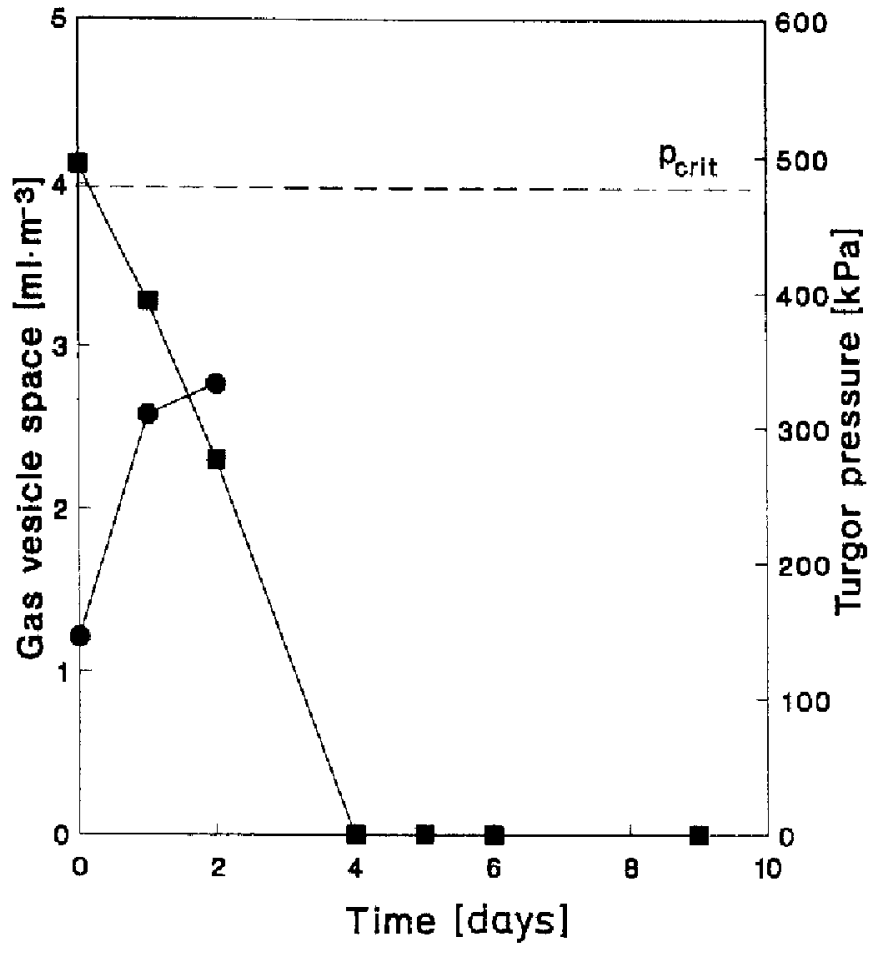

Fig. 9. Time course of cell turgor pressure (circles) and gas vesicle space (rectangles) during the same experiment as shown in Figs. 6 and 7 . The maximum pressure toleraled by isolated gas vesicles is indicated by the doshed line

(1967), who detected gas vacuoles in Pelodictyon clathratiforme strain 2730 only if cultures were transferred to very dim illumination and a temperature of $4-$ $8^{\circ} \mathrm{C}$. The same conditions did not affect the gas vesicle content in another strain ( $P$. clathratifome 1831). Similarly, Clark and Walsby (1978b) did nol observe a consistent pattern of changes in gas-vacuolation when another Pelodictyon clathratiforme strain was incubated in a light gradient. The similarity to $P$. clathratiforme 2730 suggests that the response exhibited by Pelodictyon phaeoclathratiforme may be more widespread among the green sulfur bacteria. The pattern of gas vesicle induction observed in Pelodictyon phaeoclathratiforme so far was not found in purple sulfur bacteria. In Thiopedia rosea, the gas vesicle content seems to remain constant at different incubation conditions (B. Eichler, personal communication). The same holds true for Amoebobacter purpureus and $A$. roseus (unpublished results). In Amoebobacter pendens strain 5813 the cellular gas vesicle content is controlled by the growth temperature (Eichler and Pfennig 1986).

The turgor pressure of Pelodictyon phaeoclathratiforme colls (maximum $330 \mathrm{kPa}$ ) is in the same range as determined for several cyanobacterial species $(370 \mathrm{kPa}$ in Oscillatoria agardhit, and similar values in Aphanizomenon flos-aquae, Microcystis aeruginosa, Anabaena spiroides, A. flos-aquae; Walsby and Klemer 1974). In somc of these species (e.g. Aphanizomenon flosaquae, Anabaena flos-aquae, green-colored Oscillatoria strains), increasing cell turgor pressure at high light intensities causes the weaker gas vesicles to collapse, which results in a loss of buoyancy within $30 \mathrm{~min}$ (Konopka et al. 1978; Oliver and Walshy 1984; Utkilen et al. 1985). In Pelodictyon phaeoclathratiforme, only a slow linear decline of gas vesicle volume was observed during the time course experiment. A collapse by the turgor pressure mechanism would have gonerated a rapid initial decrease of vesicle volume and a constant amount of gas vesicles after the first day of incubation. Obviously other, rather slow, processes (e.g. cleavage by proteolytic enzymes, as proposed by Walsby 1972) account for the degradation of gas vesicles in Pelodictyon cells. There is no indication for short-time buoyancy regulation at rising light intensities for this species. Rapid diurnal migrations mediated by the rapid turgor collapse mechanism as observed for Aphanizomenon flos-aquae (Konopka et al. 1978) seem unlikely in Pclodictyon phaeoclathratiforme (Fig. 9). In contrast, gas vesicles in Pelodictyon are sufficiently strong to withstand an additional hydrostatic pressure. At maximum turgor pressure, the hydrostatic pressure present at a water depth of $15 \mathrm{~m}$ will not change the amount of gas vesicles in the cells. As much lower turgor pressurc values were determined under light-limiting conditions (100-120 kPa, compare Fig. 9), gas vacuolation of Pelodictyon cells under natural conditions may remain unchanged down to a depth of $38 \mathrm{~m}$. Correspondingly, gas-vacuolated Pelodictyon cells were observed between 10 and $25 \mathrm{~m}$ in various lakes (Montesinos et al. 1983).

Variations in cellular protein and especially carbohydrate content contribute to changes in cell density of Pelodictyon phaeoclathratiforme. This is domonstrated by the agreement between the growth curve (Fig. 3) and light dependent carbohydrate content and, furthermore, the high portion of ccllular ballast explained by protein and carbohydrate. The storage polysaccharides formed during photosynthesis are metabolized again during the stationary phase thus leading to a decrease in cell density. This very closely resembles the situation in cyanobacteria where this mochanism is especially important in those species which, similarly to Pelodictyon phaeoclathratiforme, possess gas vesicles too strong to be collapsed by turgor pressure (e.g. Microcystis aeruginosa, and a redcolored Oscillatoria agardhï strain) (Kromkamp and Mur 1984; Thomas and Walsby 1985; Utkilen et al. 1985).

For the first time a third way of density change in phototrophic bacteria besides variation of gas vesicle content and ballast components was found: our results indicate a variation of tolal cell volume (including extracellular slime layers) by a factor of three. The ballast mass of carbohydrate and protein calculated on the basis of these cell volumes was in agreement with the total excess density determined separately by density centrifugation (Fig. 7A, until day 3). At maximum density, 62\% of the total ballast was explained by protein and carbohydrate, leaving about one third to be explained by other cell constituents. As our method of volume measurement is restricted to gas-vacuolated cells, no information about volume changes at higher light intensitics could be obtained. Nevertheless, comparison of protein plus carbohydrate ballast with total ballast at the end of the experiment (Fig. 7) and microscopic examination of the cells strongly indicate an incrcase of the cell volume during the stationary growth phase. 
The volume of the densest cells [6.4 $\mu] \cdot$ (mg dry cell mass) ${ }^{-1}$ is comparable to respective values in the literature. From the data of Littlewood and Postgate (1957) a cell volume of $3.23-3.48 \mu \mathrm{l} \cdot$ (mg dry cell mass) $^{-1}$ can be calculated for Desulfovibrio desulfuricans. The respective values deduced from Oliver and Walsby (1984) for Anabaena flos-aquae are in the same range $[2.0-3.53 \mu]$ - (mg dry cell mass) $\left.{ }^{-1}\right]$. However, the latter authors observed that the calculated ballast mass of protein and carbohydrate exceeded the ballast mass determined by density measurements by a factor of two to three. Correspondingly, they reported an increase of the cell volume by the Anabaena cell sheath by a factor of $2.3-2.4$; calculation of cell volumes in the manner described above ('Materials and mothods') yields values between 7.7 and $9.6 \mu 1 \cdot$ (mg dry cell mass) ${ }^{-1}$.

Microscopic observation of Indian ink preparations showed that extracellular layers occupy a large portion of the cell volume in Pelodictyon phaeoclathratiforme. From discrepancies between calculated and observed density changes in Anabaena flos-aquae, Oliver and Walsby (1984) concluded that changes in the ratio of cell volume to sheath volume may occur. There are indications that part of the total cell volume changes may be accomplished by variation of the slime layer volume (Fig. 8). For a cell which is denser than water, a slime capsule decreases its density but increases its volume. These changes have counteracting effects on the sinking rate. If the density difference between the cell (without capsule) and the slime capsule is greater than twice the density difference between slime capsule and the medium, the sinking speed is reduced for a cell surrounded by a capsule (Hutchinson 1967). Bacterial slime capsules contain about 99\% of water (Dudman 1977) and thus must have a much lower density than the cytoplasma. Changes in sinking velocity due to variation of the capsule size therefore appear very plausible. This new aspect clearly requires further investigation in the future.

In Buchensee, the population maximum of Pelodictyon phacoclathratiforme occurred between 9 and $10 \mathrm{~m}$ water depth where maximum underwater light intensity was $0.3 \mu \mathrm{mol} \cdot \mathrm{m}^{-2} \cdot \mathrm{s}^{-1}$ (Overmann and Tilzer 1989). At this illumination, a growth rate of lower than $0.1 \mathrm{~d}^{-1}$ (equal to a doubling time of $14 \mathrm{~d}$ at a 12 -h light period) was measured in pure cultures (Fig. 4B). For comparison, sinking velocities were estimated for Pelodictyon cells under in situ conditions. A minimum density value of $1010 \mathrm{~kg} \cdot \mathrm{m}^{-3}$ was determined for pressurized cells (Fig. 4B) whereas the density of the surrounding water was $998.6 \mathrm{~kg} \cdot \mathrm{m}^{-3}$ as calculated after Bührer and Ambuhl (1975). According to the Stokes equation a sphere equal in volume to the mean cell volume (Table 3 ) $(r=2.32 \mu \mathrm{m})$ would sink $16.2 \mathrm{~cm}$ within the minimum doubling time of 14 days, if density values and the viscosity of water at $7^{\circ} \mathrm{C}$ (in situ temperature) are employed. Colonies with a diameter of approximately $30 \mu \mathrm{m}$ (Fig. 8) would sink $6.76 \mathrm{~m}$ within the same time. Gas-vacuolated Pelodictyon cells reached a minimum density of $998.5 \mathrm{~kg} \cdot \mathrm{m}^{-3}$ and thus in a stable environment could maintain their vertical position even in the absence of growth. Almost all Pelodictyon cells in lake samples contained gas vacuoles. The possession of gas vesicles certainly provides a selective advantage by minimizing biomass losses due to sedimentation under conditions of light-limited growth.

Brown-colored green sulfur bacteria dominate the phototrophic bacterial community of stratified lakes in a depth range between 10 and $25 \mathrm{~m}$ (Montesinos et al. 1983). Brown Pelodictyon species were encountered in some lakes in the same depths where the non-gas-vacuolated Chlorobium phaeobacteroides was found in others. Our results indicate that these differences may result from the selective advantage provided by gas vesicles under conditions of stable stratification of the water column.

Acknowledgement. We thank Prof. A.E. Walsby for introduction into the field of gas vesicle research and for provision of equipment.

\section{References}

Bührer H, Ambühl H (1975) Einleitung von Abwasser in Seen. Schweiz Z Hydrol 37:347-369

Clark AE, Walsby AE (1978a) The occurrence of gas-vacuolate bacteria in lakes. Arch Microbiol 118:223-228

Clark AE, Walsby AE (1978b) The development and vertical distribution of populations of gas-vacuolate bacteria in a cutrophic, monomictic lakc. Arch Microbiol 118:229-233

Cohen-Bazire G, Kunisawa R, Pfennig N (1969) Comparatjue study of the structure of gas vacuoles. J Bacteriol 100:1049 - 1061

Dudinan WF (1977) The role of surface polysaccharides in natural environments. In: Sutherland I (ed) Surface carbohydrates of the prokaryotic cell. Academic Press, London New York San Francisco, pp $357-414$

Eichler B, Pfennig N (1986) Characterization of a new plateletforming purple sulfur bacterium Amoebobacter pedioformis sp. nov. Arch Microbiol 146:295-300

Hartree EF (1972) Determination of protein : a modification of the Lowry-method that gives a linear photometric response. Anal Biochem 48:422-427

Herbert D, Phipps PJ, Strange RE (1971) Chemical analysis of microbial cells. In: Norris J, Ribbons DW (eds) Methods in microbiology, vol. 5B. Academic Press, London, pp 209-344

Hutchinson GE (1967) A treatise on limnology, vol II. John Wiley, New York London Sydney

Lrgens RL, Suzuki I, Staley JT (1989) Gas vacuolate bacteria obtained from marine waters of Antarctica. Curr Microbiol $18: 261-265$

Konopka A, Brock TD, Walsby $\mathrm{AL}$ (1978) Buoyancy regulation by planktonic blue-green algae in Lake Mendota, Wisconsin. Arch Hydrobiol 83:524-537

Kromkamp JC, Mur LR (1984) Buoyant density changes in the cyanobacterium Microcystis aeruginosa due to changes in the cellular carbohydrate content. FEMS Microbiol Lett 25:105109

Littlewood D, Postgate JR (1957) On the osmotic behaviour of Desulphovibrio desulphtricans. J Gen Microbiol 16:596-603

Montesinos E, Guerrero R, Abella C, Esteve I (1983) Ecology and the competition for light between Chlorobium limicola and Chlorobium phaeobacteroides in natural habitats. Appl Environ Microbiol 46:1007-1016

Oliver RL, Kinnear AJ, Ganf GG (1981) Measurement of cell density of three freshwater phytoplankters by density gradient centrifugation. Limnol Oceanogr 26:285-294

Oliver RL, Walsby AE (1984) Direct cvidence for the role of lightmediated gas vesicle collapse in the buoyancy regulation of Anabaena flos-aquae (cyanobacteria). Limnol Oceanogr $29: 879-886$ 
Overmann I, Pfennig N (1989) Pelodictyon phaeociathratiforme sp. nov, a new brown-colored member of the Chlorobiaceae forming net-like colonies. Arch Microbivl 152:401-406

Overmann J. Tilzer MM (1989) Control of primary productivity and the significance of photosynthetic bacteria in a meromictic kettle lake, Mittlerer Buchensec, Wcst-Grermany. Aquatic Sci $51: 261-278$

Pfennig N, Cohen-Bazire $G$ (1967) Some properties of the green bacterium Pelodictyon clathratiforme. Arch Mikrobiol 59: $226-236$

Pfennig N, Wagener \$ (1986) An improwed method of preparing wet mounts for photomicrographs of microurganisms. J Microbiot Methods 4:303-306

Pfennig Y, Trüper HG (1989) Anoxygenie phototrophic bacteria. In: Stalcy IT, Bryant MP, Pfennig N, Holt JG (eds) Bergey's manual of systematic bacteriology, vol. 3. Williams and Wilkins, Baltimore, pp 1635- 1709

Stalcy IT, Irgens RL, Herwig RP (1989) Gas vacuolate bacteria from the sea ice of Antarctica. Appl Environ Mictobiol $55: 1033-1036$

Thomas RH, Walsby AE (1985) Buoyancy regulation in a stram of Microcystis. J Gen Microbiol 131: $799-809$

Utkilen HC, Skulberg OM, Walsby AE (1985) Buoyancy regulation and chromatic adaptation in planktonic Oscillatoria species: alternative strategies for optimizing light absorption in stratified lakes. Arch Hydrobiol 104:407-417

Van Liere E, Walsby AE (1982) Interactions of cyanobacteria with light. In: Carr NG, Whitton BA (eds) The biology of cyanobacteria. Blackwell Scientific Publications, Oxford, pp $9-45$

Walsby AE (1971) The pressure rolationships of gas vacuoles. Proc R Soc Lond [Biol] 178:301 - 326
Walsby AE (1972) Structure and function of gas vacuoles. Bacteriol Rev 36:1-32

Walsby AE (1973) A portable apparatus for measuring relative gas vacuolation, the strength of gas vacuoles and turgor pressure in planktonic blue-green algae and bacteria. Limnol Oceanogr $18: 653-658$

Walsby AE (1978) The properties and buoyancy-providing role of gas vacuoles in Trichodesmium Ehremberg. Br Phycol J 13:103116

Walsby AE (1980) The water relations of gas-vacuolated prokaryotes. Proc R Soc Lond [Biol] 208:73-102

Walsby AE (1981 a) Gas-vacuolate bacteria. In: Starr MP, Stolp H, Trüper HG, Balows A, Schlegel HG (eds) The prokaryotes. A handbook on habitats, isolation and identification of bacteria. Springer, Berlin Heidelberg New York, pp $441-447$

Walsby AE (1981 b) Cyanobacteria: planktonic gas-vacuolate forms. In: Starr MP, Stolp H, Trüper HG, Balows A, Schlegel HG (eds) The prokaryotes. A handbook on habitats, isolation and identification of bacteria. Springer, Berlin I Heidelberg New York, pp 224-235

Walsby AF (1982) The elastic compressibility of gas vesicles. Proc R Soc Lond [Biol] 216:355-368

Walsby AE, Klemer A (1974) The role of gas vacuoles in the microstratification of a population of Oscillatoria agardhit var: isothrix in Deming Lake, Minnesota. Arch Hydrobiol 74: 375392

Walsby AE, Kinsman R, Ibelings BW, Reynolds CS (1991) Highly buoyant colonics of the cyanobacterium Anabaena lemmernannii from persistent surface waterblooms. Arch Hydrobiol $121: 261-280$ 